Review Article

\title{
COVID-19 and Singapore: From Early Response to Circuit Breaker
}

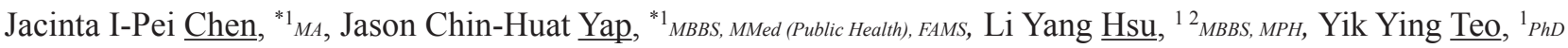

\begin{abstract}
Singapore, an island country with 5.6 million population and a large volume of tourists from mainland China, was one of the first countries to report imported COVID-19 cases and had the highest number of cases outside mainland China for a time in February 2020. The government responded with a series of broadscale public health measures and managed to contain this first wave of infection. Notwithstanding that, an evolving pandemic situation in other countries eventually triggered a second, and much larger, wave of infection. This case study narrates the developments, influencing factors, and outcomes related to events starting from Singapore's first response to COVID-19 and up to the point of its entry into Circuit Breaker. It serves as a reference for the understanding and analysis of developments in an evolving pandemic and a nation's response from a systems level perspective.
\end{abstract}

Ann Acad Med Singapore 2020;49:561-72

Key words: Containment, Coronavirus, Epidemic, Outbreak, Pandemic

\section{Background}

The COVID-19 pandemic first broke out in Wuhan, China, in December 2019, where a cluster of pneumonia cases was reported and the novel coronavirus later identified. Since then, the virus has spread rapidly across the world, registering a total of 85000 reported cases across 53 countries/territories by 29 February 2020, and more than 10 million cases across over 200 countries/ territories by 30 June $2020 .{ }^{1}$ Singapore is more than 2,500 kilometres from the southwest of mainland China (where Wuhan is situated), but received a large number of Chinese visitors with more than 400 flights between Singapore and mainland China per week. With the emergence of COVID-19 cases in Wuhan a few weeks before the Chinese New Year, during which large numbers of Chinese were expected to travel, Singapore instituted a series of broadscale public health measures to contain importation and spread of the virus. Singapore was one of the first countries to report imported cases and had the highest number of cases outside mainland China for a time from 5 February 2020. However, the rise in cases plateaued towards the end of February. ${ }^{2}$

This case study traces the developments in the early weeks of COVID-19 spread in Singapore, the government's response, and containment of this first wave. It also describes the events and incremental

\footnotetext{
"Both contributed equally in authorship.

${ }^{1}$ Saw Swee Hock School of Public Health, National University of Singapore, Singapore

${ }^{2}$ Yong Loo Lin School of Medicine, National University of Singapore, Singapore

Address for Correspondence: Ms Jacinta I-Pei Chen, Saw Swee Hock School of Public Health, Tahir Foundation Building, Block MD 1, 12 Science Drive 2, \#10-01, Singapore 117549.

Email: ephcij@nus.edu.sg
} 
measures taken in the lead-up to a second, and much larger, wave of infections that followed.

\section{The COVID-19 Situation in Singapore (23 January to 29 February 2020)}

Singapore reported its first imported case on 23 January and registered an initial rise in imported cases in the last week of that month. The first Singaporean case was reported on 31 January, and Singapore's first locally transmitted cluster was confirmed on 4 February. ${ }^{3,4}$ Early imported cases gave way gradually to locally transmitted cases. There were 5 clusters in Singapore by mid-February, 4 of which were linked to importations (Fig. 1).

As the number of new cases increased, recovered patients were, at the same time, being discharged from the hospitals. The national response in this earlier stage enabled the number of discharges to keep up with that of new admissions, so that the number of patients requiring hospital care at any one time remained manageable. The number of new admissions accelerated slightly in mid-February, disturbing this equilibrium, but levelled out again towards the end of that month.

\section{How did Singapore Respond}

\section{Whole-of-Government Response}

Learning from the SARS experience, in 2003, that an outbreak response necessitated coordinated response across sectors, the government set up a multi-ministry task force on 22 January to oversee the national response to COVID-19. It comprised members across multiple ministries, including health, trade, communications, manpower, and transport. ${ }^{5}$

After the SARS experience, the government developed a disease outbreak response plan with response levels correlating with the WHO Pandemic Alert Response system. ${ }^{6}$ The colour-coded "Disease Outbreak Response System Condition" (DORSCON) levels incorporated progressive degrees of border controls, community-based measures, infection control in hospitals, and other containment/mitigation measures. This raised awareness nation-wide, and facilitated a coordinated response, across sectors, to varying stages of infectious disease spread. On 7 February, with the discovery of several cases of COVID-19 with no links to previous cases or travel history to China, Singapore raised the DORSCON level to orange. ${ }^{7}$

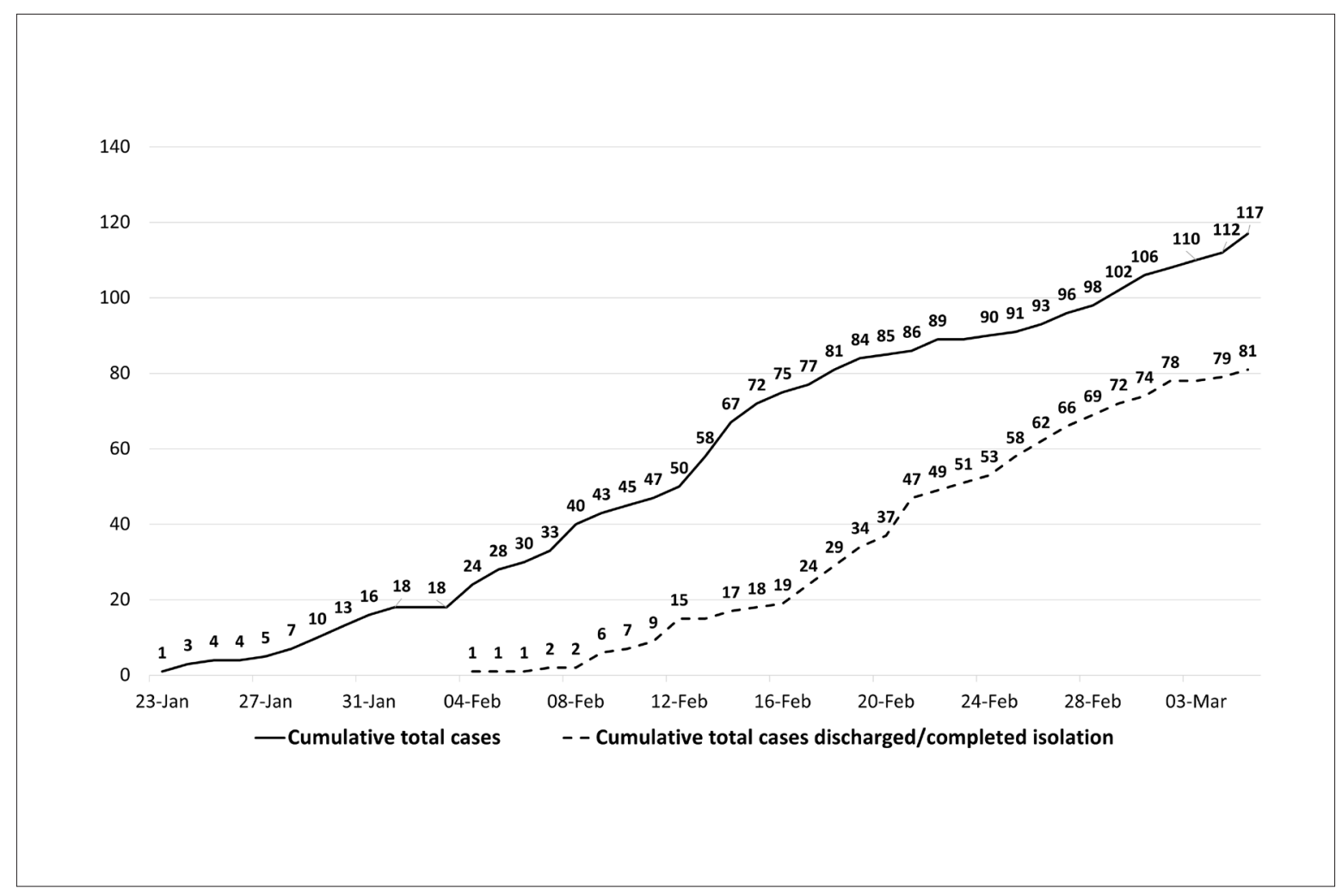

Figure 1. Total COVID-19 Cases in Singapore (as of 5 March 2020)

Data source: www.moh.gov.sg and Channel News Asia 


\section{Border Controls}

Considering the volume of visitors from China into Singapore, border control measures were introduced promptly to prevent importation of the disease into the country.

As early as 2 January, temperature screening and issuance of health advisory notices were instituted for travellers on inbound flights from Wuhan. This was later extended to inbound flights from China, land and sea checkpoints, and all flights into Singapore (Fig. 2). Concurrently, travel advisories were issued to Singaporeans to avoid travelling to Hubei. Travellers from Hubei and mainland China were denied entry into, or transit through, Singapore from 29 January and 1 February, respectively. Travellers from Hubei already in Singapore and returning travellers from Hubei had to undergo mandatory quarantine. Subsequently, a reduction in imported cases was observed and there were no reported importations from 9 February to 4 March. ${ }^{2,8,9}$

Travel restrictions were progressively adjusted as the epidemic situation in China evolved, and the source epidemic extended to secondary infections outside of Wuhan. Towards the end of February, as the disease spread moved to a stage where third generation sources were based at, and travelling from, countries outside China, denial of entry or transit was extended to travellers from Daegu and Cheongdo, South Korea.

\section{Contact Tracing, Detection, and Quarantine/Isolation}

Alongside border control measures, rapid testing, isolation of cases, contact tracing, and quarantine of suspect cases were initiated and scaled up to identify and separate infected individuals from the larger

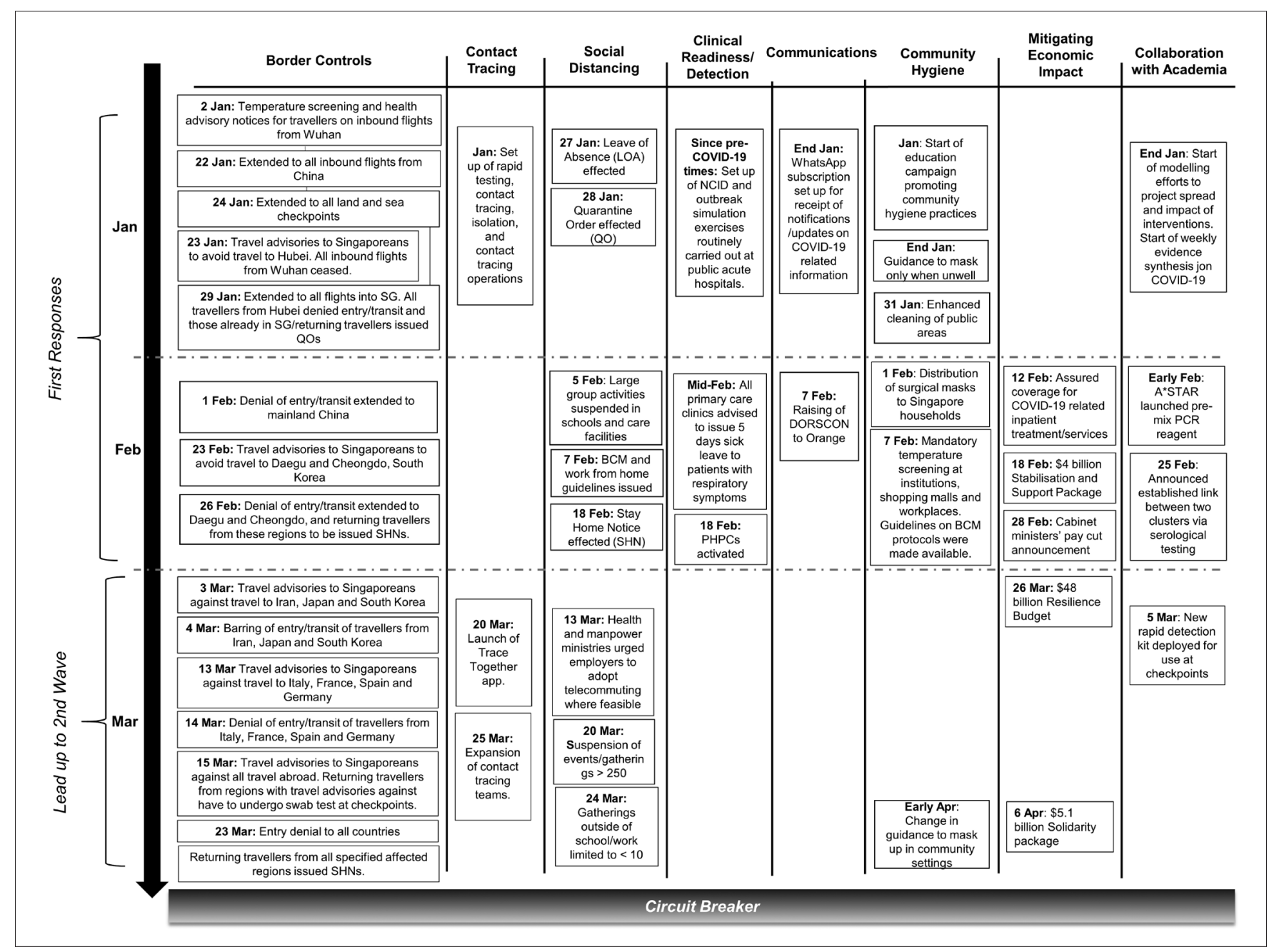

Figure 2. Key Events/Measure in Singapore's Response to the COVID-19 Pandemic (1 January to 6 April 2020) 
community. Once an infected case was confirmed, contact tracers would interview the patient and map out his/her history of movements over the last 14 days. The contact tracing team under the Ministry of Health $(\mathrm{MOH})$, then comprising communicable diseases and epidemiology experts, and volunteers from across various government departments/agencies, worked in 3 teams of 10 persons, 2 shifts a day, and 7 days a week, to identify close contacts of confirmed cases. Close contacts with COVID-19 symptoms were isolated and tested, while those without symptoms were quarantined up to 14 days from the date of last contact with the confirmed case.

$\mathrm{MOH}$ worked in partnership with the Singapore Police Force to track down contacts that could not be reached or whose identities were not known. Analytic tools helped pick out common keywords from different patients' activity logs and flagged out possible links between cases for further investigation through interviews, ground inquiries, activity mapping, and use of flight manifests and CCTV footages. Through cross referencing of attendee lists, the team also uncovered a possible link between 2 local clusters to a Chinese New Year gathering. The link was confirmed through serological testing (see section on "Collaboration with Academia and Research'). ${ }^{10-12}$

Through rapid, meticulous and thorough contact tracing, strong detection capacity was achieved. As at 16 March, $40 \%$ of confirmed cases were detected via contact tracing while they were still asymptomatic. ${ }^{13,14}$

\section{Mandatory Social Distancing}

Concurrently, 14-day mandatory social distancing, in varying levels of severity, depending on the risk profile of a suspected infection case, was effected (Table 1).

Legal enforcement of these orders was strong, with a permanent resident losing his status and barred from re-entering Singapore after breaching SHN, and a couple from China charged under the Infectious Diseases Act for breaching QO and providing untrue information to $\mathrm{MOH}$ for contact tracing. ${ }^{15,16}$

Financial assistance was also provided to residents and work-pass holders serving social distancing orders, to alleviate concerns regarding impact on livelihood which could prevent close contacts from coming forward. ${ }^{17,18}$

\section{Clinical Readiness and Response}

The 2003 SARS experience, marked by a disproportionate impact from nosocomial outbreaks, was deeply etched in the national collective consciousness and that of the healthcare sector. ${ }^{13,19}$ This translated into a culture and practice of readiness for future outbreaks in the pre-COVID-19 years. The National Centre for Infectious Diseases (NCID), a 330-bed purpose-built facility designed to strengthen Singapore's capabilities in infectious disease management and prevention, was officially opened in September 2019. Since 2014, all public acute hospitals had also been undergoing national simulation exercises of outbreak situations to train for pandemic preparedness and the expansion of isolation capacity. ${ }^{20}$

Table 1. Mandatory Social Distancing Measures

\begin{tabular}{lll}
\hline Measure & Date Effected & Description \\
\hline Leave of absence (LOA) & 27 January 2020 & $\begin{array}{l}\text { A precautionary measure to prevent the possible transmission of infections. Those on LOA should } \\
\text { stay at home, minimise contact with other people in the home, and monitor their health closely. } \\
\text { They may leave home briefly to get meals and necessities. }\end{array}$ \\
\hline Stay home notice (SHN) & 18 February 2020 & $\begin{array}{l}\text { Stricter than the LOA, but one can stay with one's family members. Those on SHN must remain in } \\
\text { their place of residence at all times during the SHN period and avoid interaction with other people } \\
\text { in the home. } \\
\text { (SHN was effected when it was found that some persons issued with LOA had continued to go out } \\
\text { of their homes regularly and infected a number of new cases as a result.) }\end{array}$ \\
\hline Quarantine order (QO) & 28 January 2020 & $\begin{array}{l}\text { Issued to suspect cases and requiring isolation from other people in the home, or in a suitable } \\
\text { government facility. A quarantine order is a directive with legal force. It has severe penalties for } \\
\text { non-compliance. } \\
\text { (Eg, from 1 to 17 February, travellers from Hubei already in Singapore and close contacts of } \\
\text { confirmed cases were issued QOs, while returning travellers from mainland China were issued } \\
\text { LOAs.) }\end{array}$ \\
\hline
\end{tabular}

Source: https://www.gov.sg/article/everything-you-need-to-know-about-the-stay-home-notice and https://www.gov.sg/article/whats-the-differencebetween-a-leave-of-absence-and-a-quarantine-order 
Public Health Preparedness Clinics (PHPCs) had been registered and prepared to be activated during public health emergencies to perform roles such as dispensing medications, administering vaccinations, and triaging or supporting the acute care hospitals. PHPCs were activated from 18 February to work alongside public primary care polyclinics to better detect and manage COVID-19 infections. These clinics, some of which had been routinely swabbing patients with influenza-like illness as part of regular sentinel surveillance, started including COVID-19 among the tests to detect community transmission. ${ }^{21}$ PHPCs also provided subsidised treatment, investigations and medications to patients with respiratory symptoms, and were guided on the risk assessment protocols for referrals to hospitals for diagnosis. ${ }^{22,23}$

From around mid-February, PHPCs and all primary care practitioners were advised to issue 5 days of mandatory sick leave to patients with respiratory symptoms to stay at home. While this helped to filter out non-COVID-19 cases (the symptoms of which would resolve after 5 days), it also effected social distancing. ${ }^{24}$

\section{Financing}

On 12 February, the government provided assurance that coverage for COVID-19 related inpatient treatment and services would be extended to all patients. ${ }^{25}$ On the same day, Singapore's insurance associations issued a joint statement confirming member companies' provision of coverage for COVID-19 related hospitalisation expenses under their policies. These early assurances addressed concerns on financial affordability and reduced potential barriers to infected persons coming forward. ${ }^{26}$

\section{Communication Strategies}

Throughout the period, frequent press briefings and public announcements were made by ministers and even the Prime Minister on the COVID-19 pandemic developments.

Apart from updates on policies and new measures, these communications prepared the public on what to expect in the weeks and months ahead, and urged them to make the necessary behavioural changes (hand hygiene practices, social distancing etc), to inhibit spread in the community. At critical junctures, the Prime Minister would address the nation. ${ }^{27}$ Concurrently, a central source of information via WhatsApp subscription was set up from which notifications on new COVID-19 updates could be received directly from the government.

With misinformation typically rampant in epidemics and leading to substantial public anxiety,${ }^{28}$ the government made special efforts to counter fake news. Clarifications on inaccurate news were frequently posted on the government's website and conveyed through traditional media. Correction directions under Singapore's Protection from Online Falsehoods and Manipulation Act (POFMA) required parties communicating falsehoods to put up clarification notices or be subject to fines/imprisonment. Several POFMA correction directions were issued to online sites for dissemination of inaccurate COVID-19 related information during the period..$^{29-33}$

Risk communications, however, did not take place without challenges and miscalculations in retrospect. For example, the announcement of the raising of DORSCON to orange sparked an episode of panic buying of groceries in the supermarkets. The Prime Minister assured the public that Singapore had sufficient stock of necessities in his address to the nation the day after, and purchase limits per person were subsequently imposed by the country's largest supermarket chain to prevent unnecessary panic buying. ${ }^{27,34} \mathrm{An}$ explanation of what the various DORSCON levels meant and entailed prior to the announcement might have prevented the panic buying episode. Since the raising of DORSCON to orange on 7 February, no subsequent references or changes to DORSCON had been made, even as the severity of the situation improved and then intensified beyond February's levels.

\section{Community Hygiene and Infection Control}

The broader communications strategy also involved a national campaign advocating social responsibility and precautionary hygiene measures. Personal/hand hygiene instructions and socially responsible behaviour were communicated through posters and comics island-wide via newspapers or at strategic locations (eg lift lobby areas, common commute points). Local celebrities further advocated for them on social and traditional media (Fig. 3.)

As public education with a participatory approach tends to encourage voluntary compliance with community hygiene measures, ${ }^{35-37}$ the government took pains to address community feedback. For example, from January to March, because the evidence for facemask use at the population level was uncertain (largely due to high variability in proper use and compliance), the limited supplies had to be prioritised for healthcare workers, and there was as yet no widespread community transmission, the national guidance was to don masks only when one was feeling unwell. This prompted public concern, followed by several rounds of explanation by ministers 
at press briefings on the rationale for the guidance. Notwithstanding the explanations, with facemasks sold out at retail outlets island wide, there was still widespread concern about their shortage even if used only when one was unwell. In response, a set of 4 surgical masks was distributed to each of the 1.37 million Singapore households from 1 February. ${ }^{38}$

Concurrently, from 31 January, enhanced cleaning of public areas was carried out. ${ }^{39,40}$ Large group and communal activities were also suspended in schools and social and elder care facilities from 5 February, ${ }^{41-43}$ and mandatory temperature taking was undertaken at institutions, shopping malls and workplaces from 7 February (in response to the raising of DORSCON Yellow to Orange) (Fig. 2)..$^{44,45}$

\section{Mitigating the Economic Impact}

As containment measures were stepped up across the country, fiscal measures were introduced to alleviate the impact to businesses and citizens' livelihoods. On 18 February, the government announced a SGD4 billion Stabilisation and Support Package which co-paid portions of local workers' wages, granted tax rebates, and provided cashflow-assisting measures for the more badly hit sectors. ${ }^{46}$ Two more sets of fiscal measures were introduced later as the outbreak situation evolved and economic impact deepened (see section below on "In The Lead Up to 'Circuit Breaker'").

Concurrently, organisations prepared and commenced business continuity management (BCM) protocols. Locally contextual guidelines were made available..$^{47,48}$

\section{Collaboration with Academia and Research}

In planning the response, the government also harnessed the academia and research institutes. Epidemiological models were co-created at the Saw Swee Hock School of Public Health, National University of Singapore, with $\mathrm{MOH}$, to project disease spread and simulate the reductive impact under different intervention scenarios. ${ }^{49,50}$ The large amount of academic literature emerging on COVID-19 also meant it was challenging for the government to digest

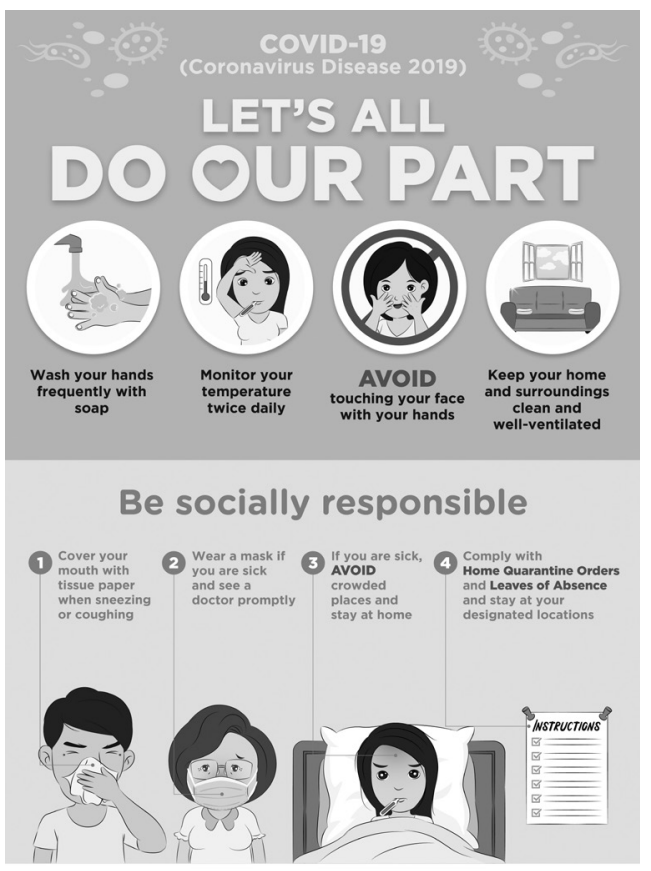

WE WILL GET THROUGH THIS!

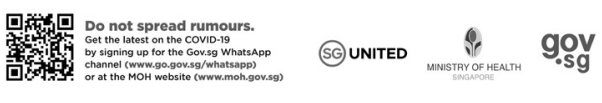

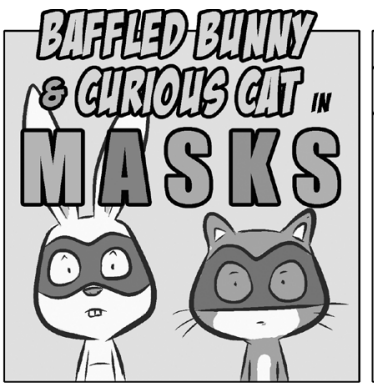
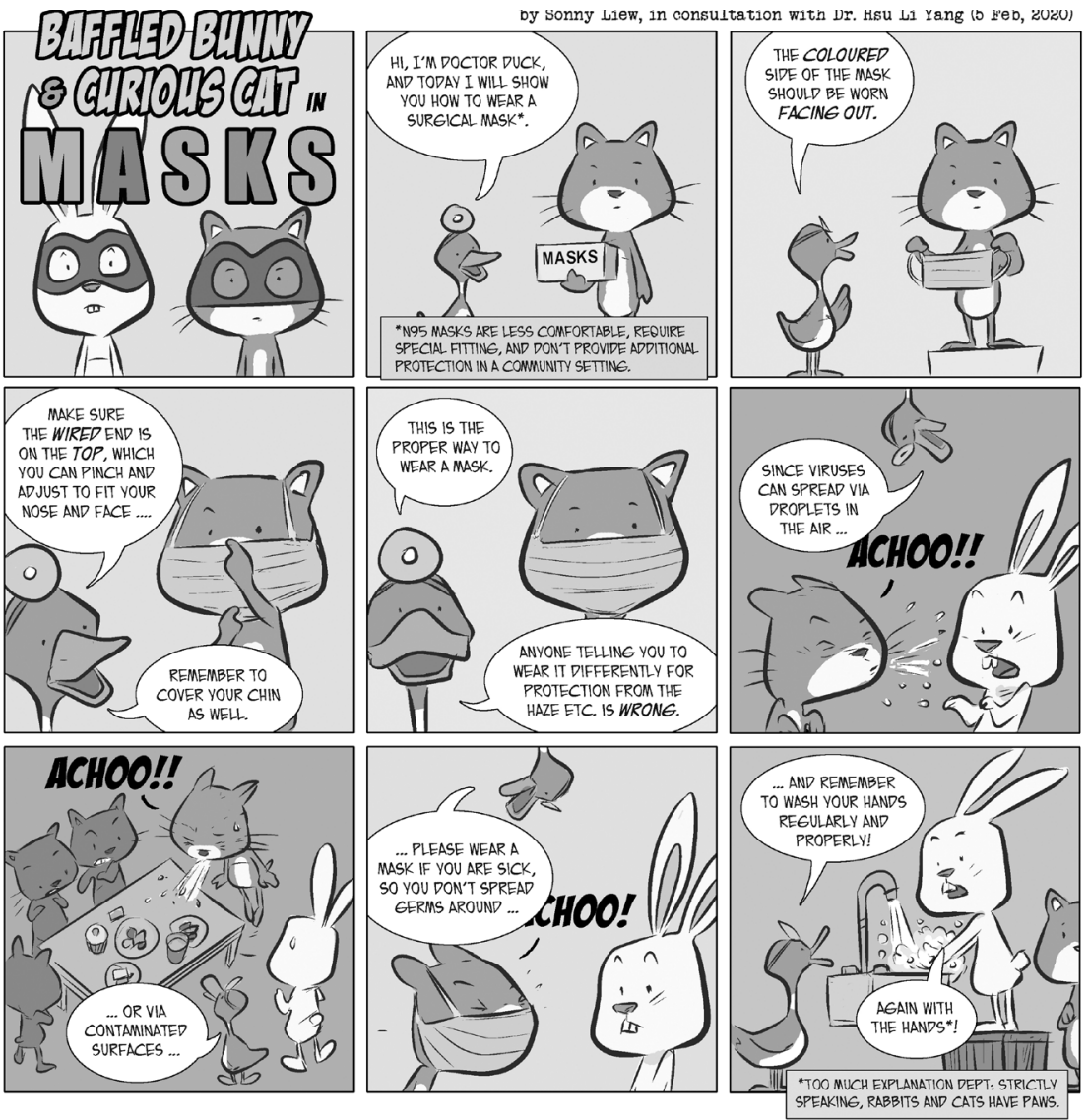

Figure 3. National Campaign on COVID-19

Source: (Left) Poster from https://www.moh.gov.sg/COVID-19/resources, (right) comics by Sonny Liew, in consultation with Hsu Li Yang. 
relevant information that could inform policymaking. The School conducted rapid and weekly evidence synthesis on the key topics of vaccines, diagnostics, therapeutics, clinical characteristics and containment measures to support the government. ${ }^{51}$

On diagnostics and surveillance, the Agency for Science, Technology and Research launched a pre-mix PCR reagent which could reduce laboratory test time by $30 \%{ }^{52,53} \mathrm{~A}$ rapid detection kit launched by a biotechnology company was used to test travellers entering Singapore with COVID-19 like symptoms. ${ }^{54}$ The use of new serological testing from the Duke-NUS Medical School, which uses antibody tests and is able to confirm earlier infection in asymptomatic persons, also helped uncover a missing link between 2 clusters in late February. ${ }^{55}$ Such collaborative efforts facilitated the mounting of a scientific and evidence-guided national response.

\section{Enabling Factors}

After the broadscale implementation of measures, the number of newly reported cases started to decline from mid-February, and Singapore reported between 0-3 new cases each day from 19 to 28 February.

A number of factors unique to Singapore's situation enabled its effective response to this first wave of infection. The small size of the island nation meant that there were limited points of entry for travellers without the added complexity of inter-state travel and coordination of policy implementation across states or provinces. Singapore's populace has also been accustomed to national campaigns, for example those encouraging behavioural changes (such as speaking good English, or being courteous), being regular features in the country's history.

As a democratic republic with a one-party dominant system since the country's independence, the people and the government have a longstanding relationship with a reasonable degree of trust. ${ }^{56}$ In addition, Singapore has sufficient resources to provide the fiscal response that helped cushion economic impact to businesses.

\section{Start of a New Wave (1 March to 14 April)}

Despite the success of Singapore's first responses, continued vigilance and preparation for new infections was necessary in the evolving pandemic situation. In early March, the government was already warning that Singapore needed to be prepared for new spikes in COVID-19 cases. Shortly after, daily reported new cases shifted into the double-digit range, driven mainly by a dinner function event which became Singapore's largest cluster of 43 cases by 12 March (Figure 4). ${ }^{57-59}$
Concurrently, with the spread of COVID-19 across other countries, the number of imported cases started to rise. The first imported case since 9 February was reported on 4 March, and this grew to a peak of 42 by 24 March (Fig. 5). A series of extended border control measures was implemented over this period, with travel advisories to Singaporeans to avoid travel to specific countries, and the barring of entry of travellers from these countries. These started with Iran, northern Italy, Japan and South Korea from 3 March, then extended to Italy, France, Spain and Germany, ASEAN countries, Switzerland, and the UK, and then to all countries by 23 March (Fig. 2). At the same time, returning travellers from these specified regions were issued SHNs and had to undergo a swab test (from 15 March). Noting that the largest share of imported cases was from the UK and US, those returning from these countries also had to serve their SHNs at designated hotels from 25 March., ${ }^{2,60}$ The peak of 48 imported cases started to come down from 23 March and tapered off to 0 by 10 April.

However, with the huge number of returning residents, and family members of persons under SHN continuing to interact with the community, subsequent local spread took hold. Local transmission cases rose and overtook imported cases from end March (Fig. 5). By 31 March, there was a total of 16 detected local clusters, and the cumulative number of COVID-19 cases reached 1,000 on 1 April. ${ }^{61,62}$

\section{In the Lead Up to 'Circuit Breaker'}

As the number of local cases climbed, social distancing measures were stepped up. Events and gatherings with 250 or more participants were suspended, and this was later extended to gatherings with 10 or more people. ${ }^{63,64}$ Initial urging by the government for employers to facilitate telecommuting by staff, where possible, eventually became compulsory under the Infectious Diseases Act. Retailers and food and beverage operators had to put in place markings (for example, on the floor, or on tables and chairs) and limit the number of patrons to ensure sufficient space (at least 1 metre apart) between them. ${ }^{65-67}$ Singapore's contact tracing teams were also expanded from the hitherto 3 (when daily new cases were mostly in single digits and cumulative cases were below 200) to 20, to prepare for an expected surge in COVID-19 cases as daily new cases moved into double digit numbers and cumulative cases crossed $500 .{ }^{12} \mathrm{~A}$ contact-tracing application (TraceTogether), which allowed contact tracers to easily identify other users a patient has been in close contact with, was also launched on 20 March. $^{68}$ 


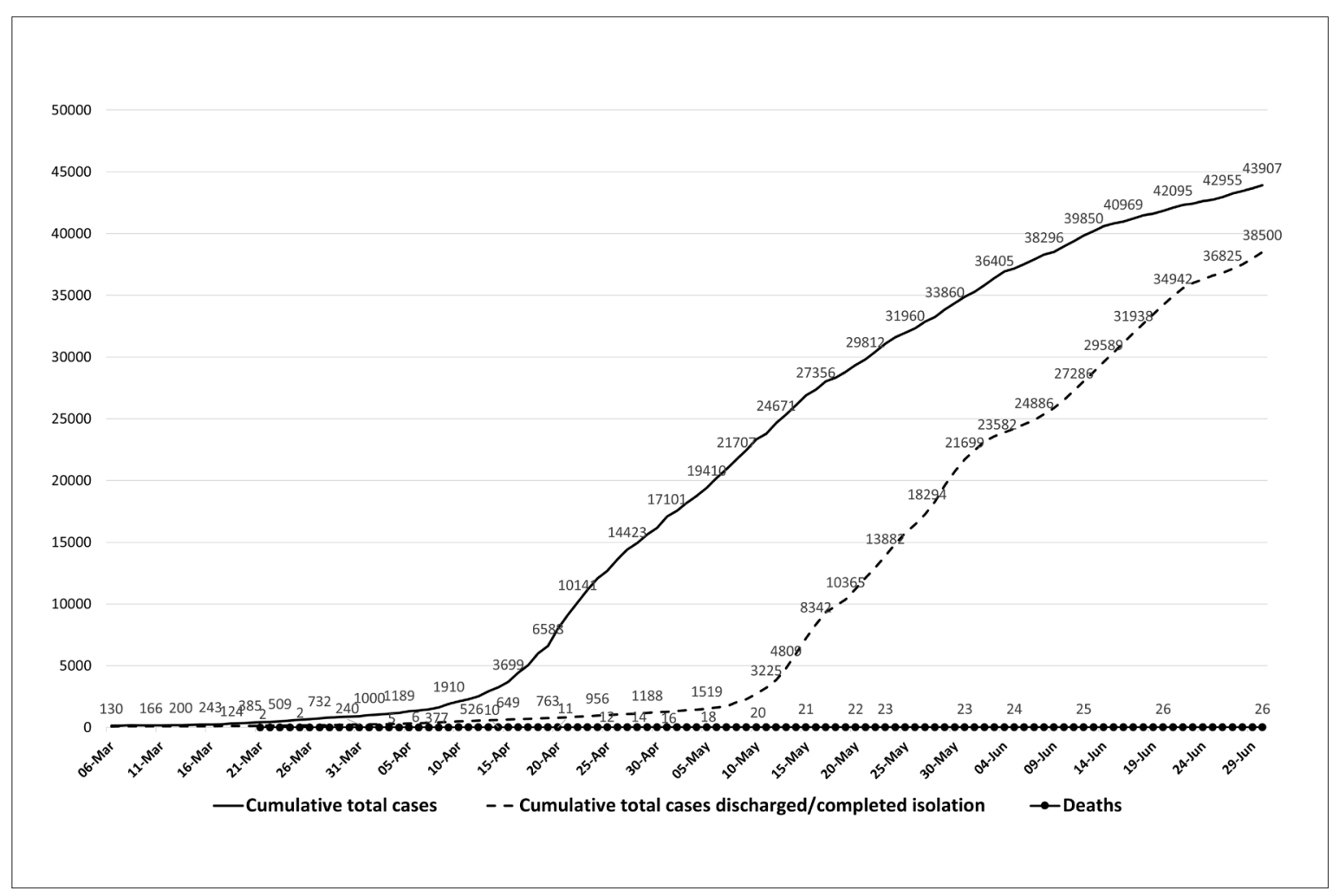

Figure 4. Total COVID-19 Cases in Singapore (6 March 2020 to 14 April 2020) Data sources: https://www.moh.gov.sg/COVID-19/situation-report

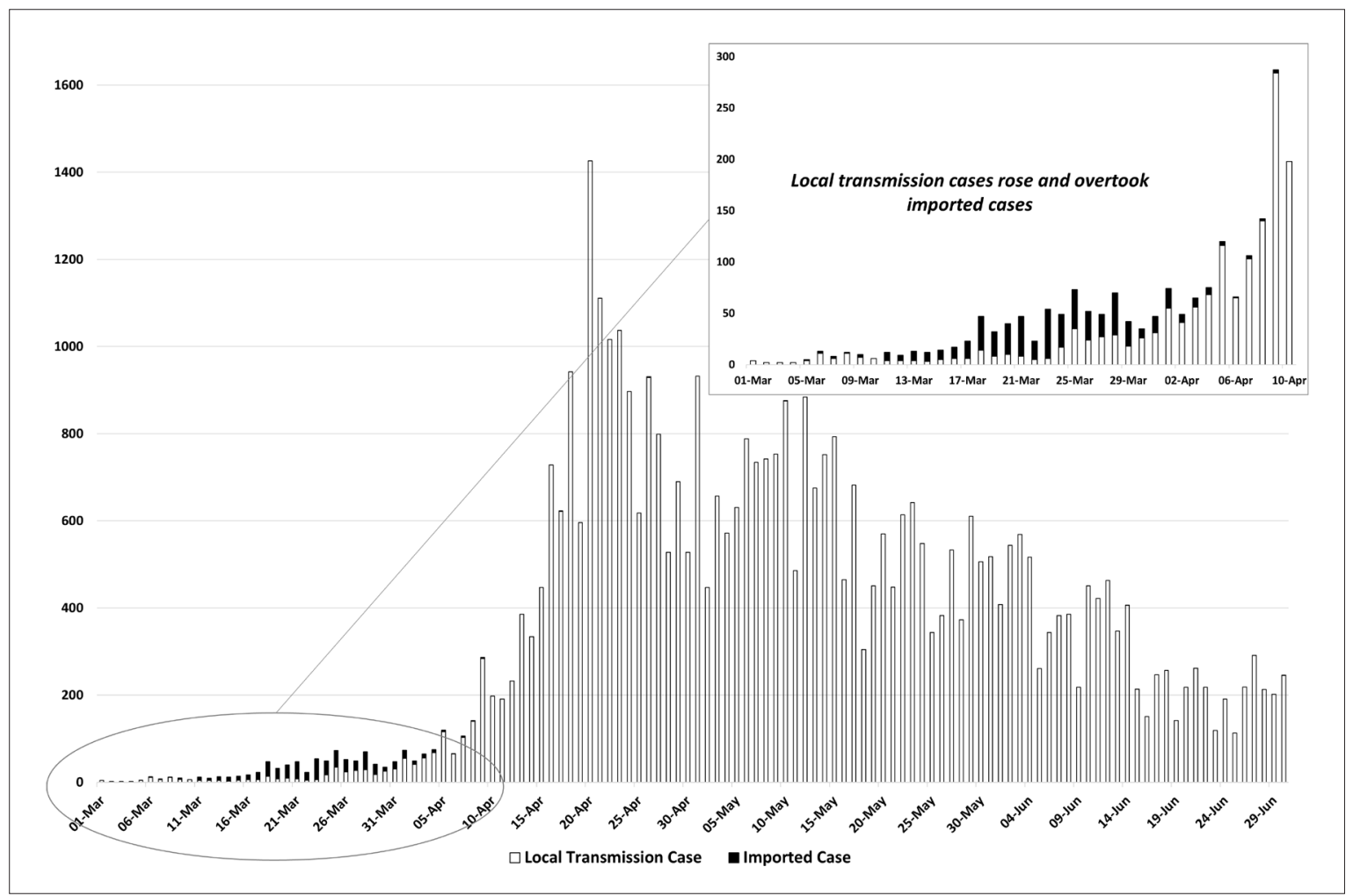

Figure 5. Daily imported and local transmission cases (1 March 2020 to 14 April 2020) Data source: www.moh.gov.sg 
At the same time, the second set of fiscal measures (a SGD48 billion Resilience Budget) was introduced to further alleviate the deepening impact to businesses on 26 March. Earlier fiscal measures were enhanced with higher co-funding (up to $75 \%$ ) of wages, extended corporate tax treatments, enhanced financing schemes (with government risk-sharing) for Singapore-based enterprises, and additional rebates for the tourism, land transport and aviation sectors. ${ }^{69}$ Meanwhile, opportunities were created for airline crew to be directed to appropriate jobs in supporting roles in hospitals, and for taxi drivers to take on grocery delivery work (see Fig. 2 for a summary of key events/measures in Singapore's response to the COVID-19 pandemic). ${ }^{70-72}$

\section{Circuit Breaker}

Local transmission cases continued to rise, and a decisive move was made with the Prime Minister announcing the closure of most workplaces and full home-based learning for schools from 7 April (part of a suite of significantly stricter island-wide measures termed a 'Circuit Breaker' (see Table 2)). In view of the widespread community transmission, and more definitive evidence of asymptomatic transmission, a change was made to the national guidance on masking, which became a requirement by law when one stepped out of one's home from 14 April. $^{73}$

Meanwhile, the Solidarity package (third set of fiscal measures amounting to SGD5.1 billion) was announced on 6 April (Table 2). ${ }^{74}$

\section{Foreign Worker Dormitories}

Perhaps most worryingly, just as Singapore shifted into 'circuit breaker' mode, large clusters emerged in foreign worker dormitories. There are about 300000 migrant workers employed in low-wage jobs living in purposebuilt dormitories and factory-converted dormitories across the island. ${ }^{77,78}$ On 5 April, 2 purpose-built dormitories were gazetted as isolation areas to stem transmission of COVID-19 in the community. Such gazetted dormitories grew to 25 by 24 April. . $^{79,80,81}$

The government set up an inter-agency taskforce to provide support to foreign workers and dormitory operators during this period. The frequency of cleaning and disinfection of the dormitories was increased, and teams of government personnel were sent in to help the dormitories implement safe distancing measures. Doctors, nurses, and swab testing teams were also progressively deployed to the dormitories to tend to workers who were unwell, to swab those with symptoms, and to manage cases that needed to be sent to other facilities. In addition, workers involved in essential services were moved out to alternative types of accommodations to minimise the risk of healthy workers getting infected and disruption to essential services. ${ }^{82,83}$

\section{Concluding Points}

On 14 April, there were more than 40 detected clusters in Singapore, and the cumulative number of COVID-19 cases had reached 3,252, with daily new cases in the range of hundreds and foreign worker dormitory cases comprising the large majority. ${ }^{84}$

Table 2. Brief Summary of 'Circuit Breaker' Measures (as at 3 April 2020) ) $^{74-76}$

\begin{tabular}{|c|c|}
\hline Sectors & Measures \\
\hline Education & $\begin{array}{l}\text { Schools and Institutes of Higher Learning will move to full home-based learning. Preschools and } \\
\text { student care centres will suspend services. (Schools, preschools and student care centres will provide } \\
\text { limited services for children of parents who are workers in essential sectors.) }\end{array}$ \\
\hline Public & $\begin{array}{l}\text { Members of the public strongly advised to stay home except to purchase daily necessities, or seek } \\
\text { essential services or urgent medical care. Reusable masks to be distributed to all Singapore residents. }\end{array}$ \\
\hline Attractions/recreation facilities & $\begin{array}{l}\text { All attractions, theme parks, museums, casinos, and sports and recreation facilities will be closed. } \\
\text { Restaurants/cafes/dining outlets will operate only for takeaways. }\end{array}$ \\
\hline Essential sectors & $\begin{array}{l}\text { Essential services and those in economic sectors critical for local and global supply chains (eg. food, } \\
\text { health, transport/storage, infocomms and banking/finance sectors) will remain open. }\end{array}$ \\
\hline Across sectors & $\begin{array}{l}\text { Solidarity Package announced on } 6 \text { April extended } 75 \% \text { co-funding of wages to every local } \\
\text { employee for } 1 \text { month, increased government risk-share of financing loans to businesses to } 90 \% \text {, and } \\
\text { issued cash payouts to Singaporeans, among others. }\end{array}$ \\
\hline
\end{tabular}


These went on to new highs, and cumulative COVID-19 cases were over 40,000 by June. Despite extensive efforts, Singapore ended up experiencing a higher number of new cases per day during the Circuit Breaker than before.

While efficient contact tracing and a broad and multi-sectoral approach mitigated and contained rising cases in February, yet maintaining societal and economic functioning, some policy decisions made in a rapidly evolving pandemic with limited information may have inevitably permitted the more extensive spread after March. Earlier border closures might have reduced the extent of imported and subsequent community cases. A more pre-emptive national masking advice might have slowed community transmission that led to Singapore's second wave. SHNs for all returning residents could have been served at designated facilities instead of in their own homes, and preventive measures could have been instituted early at foreign worker dormitories as an identifiable setting with higher transmission risk. It is also worth reflecting on how the DORSCON, based on Singapore's SARS experience, which was similar but different in some key aspects, actually performed as a guide to systemic policy responses across varying degrees of outbreak severity.

After successful containment of a first wave originating from Wuhan and mainland China, the returning of residents from other countries in an evolving pandemic situation had triggered the start of a second and much larger wave of infections. The circuit breaker and measures deployed at foreign worker dormitories marked the start of a second and even more challenging phase of national responses to the COVID-19 pandemic.

\section{Acknowledgements}

We are grateful to the following for their assistance on the search and collation of relevant content for the article: Rowena Kah Sin Yap, Sylvia Phua Yi Hui, Thng Zheng Huan, Javier

\section{REFERENCES}

1. WHO. Coronavirus disease (COVID-2019) situation reports, 2020. Available at:https://www.who.int/emergencies/diseases/novelcoronavirus-2019/situation-reports. Accessed on 23 July 2020.

2. Ministry of Health. Past Updates On COVID-19 Local Situation, 2020. Available at:https://www.moh.gov.sg/COVID-19/past-updates. Accessed on 27 July 2020

3. Mahmud AH. What we know about the locally transmitted coronavirus cases in Singapore. Channel News Asia. 4 February 2020.
4. Goh T. Wuhan virus: First Singaporean case confirmed; she was on Scoot flight from Wuhan. The Straits Times. 31 January 2020.

5. The Straits Times. Wuhan virus task force: Singapore's high-powered members. The Straits Times. 27 January 2020.

6. Ministry of Health. MOH Pandemic Readiness and Response Plan for Influenza and other Acute Respiratory Diseases, April 2015. Available at:https://www.moh.gov.sg/docs/librariesprovider5/ diseases-updates/interim-pandemic-plan-public-ver-_april-2014.pdf. Accessed on 23 July 2020.

7. Ministry of Health. Risk Assessment Raised To Dorscon Orange. News Highlights, 7 February 2020. Available at:https://www.moh.gov. sg/news-highlights/details/risk-assessment-raised-to-dorscon-orange. Accessed on 23 July 2020.

8. gov.sg. How is Singapore limiting the spread of Coronavirus disease 2019? Online, 12 February 2020. Available at:https://www. gov.sg/article/how-is-singapore-limiting-the-spread-of-COVID-19. Accessed on 27 July 2020.

9. Ministry of Health. Additional Precautionary Measures in Response to Escalating Situation In Daegu and Cheongdo, 25 February 2020. Available at:https://www.moh.gov.sg/news-highlights/details/ additional-precautionary-measures-in-response-to-escalating-situationin-daegu-and-cheongdo. Accessed on 27 July 2020.

10. The Straits Times. A guide to Singapore's COVID-19 contact-tracing system, 28 March 2020. Available at:https://www.straitstimes.com/ multimedia/a-guide-to-singapores-COVID-19-contact-tracing-system. Accessed on 27 Julu 2020

11. Baharudin H. Coronavirus: S'pore Government to make its contact-tracing app freely available to developers worldwide. The Straits Times. 23 March 2020.

12. Mahmud AH. COVID-19: Singapore expands contact tracing teams to prepare for surge in cases. Channel News Asia. 25 March 2020.

13. Lim J. Singapore's Experience - COVID-19, 18 March 2020. Available at:https://sph.nus.edu.sg/2020/03/singapores-experiencetackling-COVID-19/. Accessed on 27 July 2020.

14. Vaswani K. Coronavirus: The detectives racing to contain the virus in Singapore contain the virus in Singapore. BBC News. 19 March 2020.

15. CNA. Man loses PR status, barred from re-entering Singapore after breachng Stay-Home Notice. Channel News Asia. 26 February 2020.

16. Lam L. China couple charged under Infectious Diseases Act for obstructing COVID-19 containment work. Channel News Asia. 28 February 2020.

17. Khalik S. Wuhan virus: $\$ 100$ a day for those quarantined; severe penalties for people who flout quarantine orders. The Straits Times. 28 January 2020.

18. NTUC. Tripartite Care Package for Taxi and Private Hire Drivers placed on Quarantine due to Wuhan Coronavirus, 1 February 2020. Available at:https://www.ntuc.org.sg/wps/portal/up2/home/news/ mediareleases/mediareleasesdetails?WCM GLOBAL CONTEXT=/ Content Library/ntuc/home/about $\% 20$ ntuc/newsroom $/$ media\%20 releases/fa696f01-912d-44a3-a374-f2dcb5fedfe2. Accessed on 28 July 2020.

19. Dan YY, Tambyah PA, Sim J, Lim J, Hsu LY, Chow WL, et al. Costeffectiveness analysis of hospital infection control response to an epidemic respiratory virus threat 2009; Emerg Infect Dis, 15:1909-16.

20. Lum LHW, Badaruddin H, Salmon S, Cutter J, Lim AYT, Fisher D. Pandemic preparedness: nationally-led simulation to test hospital systems. Ann Acad Med Singapore 2016; 45:332-7.

21. Lee VJ, Chiew CJ, Wei XK. Interrupting transmission of COVID-19: lessons from containment efforts in Singapore. Journal of Travel Medicine 2020;1-5. 
22. Goh T. Coronavirus: More patients with respiratory symptoms at PHPCs, but some afraid 5-day MC will affect income. The Straits Times. 24 February 2020.

23. Hsu LY, Chia PY, Lim JFY. The novel coronavirus (SARS-CoV-2) epidemic. Ann Acad Med Singapore. 2020 Mar 16;49(3):105-107.

24. Lai L. Coronavirus: Docs to give 5-day medical leave to patients with respiratory symptoms; subsidised rates for S'poreans at designated clinics. The Straits Times. 14 February 2020.

25. Choo YT. Coronavirus: Singapore Government to foot bills of infected patients at public hospitals, except outpatient expenses. The Straits Times. 12 February 2020.

26. Olano G. Singapore insurance associations issue joint statement on coronavirus. Insurance Business Asia. 12 February 2020.

27. Prime Minister's Office Singapore. PM Lee Hsien Loong's remarks in English, Chinese and Malay, as well as translated into Tamil, on the Coronavirus Disease 2019 (COVID-19) situation in Singapore, delivered on 8 February 2020, 25 February 2020. Available at:https:/www.pmo.gov.sg/Newsroom/PM-Lee-Hsien-Loong-on-theNovel-Coronavirus-nCoV-Situation-in-Singapore-on-8-February-2020. Accessed on 28 July 2020

28. Ong EK, Lim CH, Wong AJTY. The Role of Social Media during the COVID-19 Pandemic. Ann Acad Med Singapore 2020;49.

29. Kamil A. Health Minister asks Pofma office to issue correction direction to States Times Review over COVID-19 post. Today Online. 14 February 2020.

30. CNA. Health Minister orders POFMA correction directions to States Times Review, Facebook over COVID-19 post. 14 February 2020.

31. Channel News Asia. Wuhan virus: POFMA Office issues correction direction to Facebook over posts claiming Woodlands MRT closure. Channel News Asia. 28 January 2020.

32. Yang Y. Commentary: What to do with all these health rumours and forwarded messages in the time of COVID-19. February 2020, 13.

33. SingaporeLegalAdvice.com. Singapore Fake News Laws: Guide to POFMA (Protection from Online Falsehoods and Manipulation Act), 3 February 2020. Available at:https://singaporelegaladvice. com/law-articles/singapore-fake-news-protection-online-falsehoodsmanipulation/\#falsehood. Accessed on 28 July 2020.

34. Tan A, Wong C, Zhuo T. FairPrice limits purchases of paper products, rice, instant noodles and vegetables amid coronavirus outbreak. The Straits Times. 9 February 2020.

35. World Health Organization. Managing epidemics: Key facts about major deadly diseases, 2018. Available at:https://www.who.int/ emergencies/diseases/managing-epidemics-interactive.pdf. Accessed on 24 July 2020

36. Blendon RJ, DesRoches CM, Cetron MS, Benson JM, Meinhart T, Pollard W, et al. Attitudes toward the use of quarantine in a public health emergency in four countries. Health Affairs 2006; 25.

37. Gostin LO. Public Health Law: Power, Duty, Restraint (Second Edition). New York and Berkeley : Milbank Memorial Fund and University of California Press, 2007

38. Wong PT. Govt to distribute masks to all 1.37 million Singapore households amid Wuhan virus outbreak. Today. 30 January 2020.

39. National Environment Agency. News. "SG Clean" Campaign Launched To Rally Public And Businesses To Work Together To Keep Singapore Clean, 17 February 2020. Available at:https://www. nea.gov.sg/media/news/news/index/sg-clean-campaign-launched-torally-public-and-businesses-to-work-together-to-keep-singapore-clean. Accessed on 23 July 2020
40. National Enviornment Agency. Public Cleanliness. Environmental Cleaning Guidelines, 30 June 2020. Available at:https://www.nea.gov. sg/our-services/public-cleanliness/environmental-cleaning-guidelines. Accessed on 23 July 2020

41. Ang J. Coronavirus: Assemblies, large group activities in S'pore schools to be suspended. The Straits Times. 4 February 2020.

42. National Council of Social Services (NCSS). Enhanced Precautionary Measures for Residential and Community-based Facilities Against COVID-19 (Coronavirus Disease 2019), 18 February 2020. Available at:https://www.ncss.gov.sg/NCSS/media/NCSS-Advisories/180220Advisory-on-Enhanced-Precautionary-Measures-for-Residential-andCommunity-based-Facilities.pdf. Accessed on 24 July 2020.

43. Iskandar H, Rosli TM. Coronavirus: Large group activities in schools suspended. The New Paper. 5 February 2020.

44. Chong Clara. Coronavirus: Long queues form on first day of temperature screening at office buildings. The Straits Times. 10 February 2020.

45. Ministry of Manpower. Advisories on COVID-19. General advisory for workplace measures in response to DORSCON Orange situation in Singapore, 20 March 2020. Available at:https:/www.mom.gov.sg/ COVID-19/general-advisory-for-workplace-measures. Accessed on 24 July 2020

46. Ministry of Finance. Budget 2020: Advancing As One Singapore. A Singapore Government Agency Website, 18 February 2020. Available at:https://www.singaporebudget.gov.sg/budget_2020/ about-budget/budget-media-releases/budget-2020-advancing-as-onesingapore. Accessed on 24 July 2020.

47. Ministry of Manpower. General advisory for workplace measures in response to DORSCON Orange situation in Singapore, 7 February 2020. Available at:https://www.mom.gov.sg/2019-ncov/general-advisory-forworkplace-measures. Accessed on 28 July 2020.

48. Morgan Lewis \& Bockius LLP. Responding to the 2019 Novel Coronavirus: Guidance for Singapore Employers, 2020. Available at:https://www.lexology.com/library/detail.aspx?g=514a0d8e-847f479d-8f69-b7f93b959b2a. Accessed on 28 July 2020.

49. Koo JR, Cook AR, Park M, Sun Y, Sun H, Lim JT, et al. Interventions to mitigate early spread of SARS-CoV-2 in Singapore: a modelling study. Lancet Infect Dis 2020; 20:678-688.

50. Potential Rapid Diagnostics, Vaccine and Therapeutics for 2019 Novel Coronavirus (2019-nCoV): A Systematic Review. Pang, J, et al. 3, 2020, Journal of Clinical Medicine, 9, p. 623.

51. Saw Swee Hock School of Public Health. Research on COVID-19. SSHSPH COVID-19 Science Reports, 2020. Available at:https://sph. nus.edu.sg/COVID-19/research/. Accessed on 24 July 2020.

52. Tan A. Coronavirus: Made-in-Singapore diagnostics test rolled out at some hospitals here. The Straits Times. 8 February 2020.

53. Agency for Science, Technology and Research (A*STAR). News. Fighting COVID-19 with Fortitude, 27 May 2020. Available at:https:// www.a-star.edu.sg/News-and-Events/a-star-news/news/COVID-19/ fighting-COVID-19-with-fortitude. Accessed on 24 July 2020

54. SEKISUI veredus. VereCoVTM (IVD), 2020. Available at:https:// vereduslabs.com/products/infectiousdiseases/verecov/. Accessed on 28 July 2020

55. CNA. Duke-NUS used COVID-19 antibody tests to establish link between church clusters in a world-first. Channel News Asia. 25 February 2020.

56. Edelman. Global Report: Edelman Trust Barometer 2019, 2019. Accessed on 28 July 2020. Available at:https://www.edelman.com/ 
sites/g/files/aatuss191/files/2019-02/2019_Edelman_Trust_Barometer_ Global_Report.pdf.

57. Goh T. Be mentally prepared for spike in coronavirus cases in Singapore, says Lawrence Wong. The Straits Times. 4 March 2020.

58. Kamil A. COVID-19: 9 more cases in S'pore, as Safra Jurong cluster continues to grow. Today. 14 April 2020.

59. Yip WY. Coronavirus: CNY celebration by singing group led to second-largest cluster here. The Straits Times. 8 March 2020.

60. Chew HM. Returning Singapore residents from UK, US to serve stay-home notices at hotels. Channel News Asia. 24 March 2020.

61. Kamil A. COVID-19: 35 new cases reported; 3 new clusters emerge, including 1 at a live music bar on Circular Road. Today. 30 March 2020.

62. Kamil A. COVID-19: 47 more cases in S'pore, new cluster at Westlite Toh Guan dormitory at Westlite Toh Guan dormitory. Today. 31 March 2020.

63. Baker JA. COVID-19 temporary measures: Gatherings outside of school and work limited to 10 people, entertainment venues to close. Channel News Asia. 24 March 2020

64. Mahmud AH, Darke A. All events, gatherings with 250 participants or more must be suspended to reduce further COVID-19 spread: $\mathrm{MOH}$. Channel News Asia. 20 March 2020.

65. Co C, Tang SK. Safe distancing rules still a work in progress for some businesses days after announcement. Channel News Asia. 22 March 2020.

66. The Straits Times. Firms urged to stagger work hours, let staff work from home. The Straits Times. 14 March 2020.

67. Yong M. COVID-19: Jail, fines for employers who do not allow employees to work from home where possible. Channel News Asia. 2 April 2020.

68. Koh Dean. Singapore government launches new app for contact tracing to combat spread of COVID-19. mobihealthnews, 20 March 2020. Available at:https://www.mobihealthnews.com/news/asia-pacific/ singapore-government-launches-new-app-contact-tracing-combatspread-COVID-19. Accessed on 25 July 2020.

69. Ministry of Finance. Budget 2020: Stabilisation And Support Package, 3 April 2020. Available at:https://www.singaporebudget.gov. sg/budget_2020/budget-measures/stabilisation-and-support-package. Accessed on 28 July 2020

70. CNA. COVID-19: Singapore Airlines to provide 300 'care ambassadors' to fill manpower gap at hospitals. Channel News Asia. 3 April 2020.

71. The Straits Times. SMRT waives taxi rents for four weeks; partners other firms for drivers to deliver food and parcels. The Straits Times. 4 April 2020.
72. Mokhtar F, Jamrisko M. Singapore Boosts Virus Package to $11 \%$ of GDP, Tap Reserves. Bloomberg , 26 March 2020. Available at:https://www.bloomberg.com/news/articles/2020-03-26/singaporeboosts-virus-package-to-11-of-gdp-draws-on-reserves. Accessed on 24 July 2020.

73. Tay TF. Coronavirus: Mandatory for all in Singapore to wear mask when out, except for kids under 2 and those doing strenuous exercise. The Straits Times. 14 April 2020.

74. Ministry of Finance. Supplementary Budget 2020: Our Solidarity Budget, 2020. Available at:https://www.singaporebudget.gov.sg/ budget_2020/solidarity-budget/solidarity-budget-measures/solidaritybudget-booklet-eng. Accessed on 28 July 2020.

75. Mohan M, Ang HM. COVID-19: Singapore makes 'decisive move' to close most workplaces and impose full home-based learning for schools, says PM Lee. Channel News Asia. 3 April 2020.

76. Channel News Asia. PM Lee on COVID-19 situation: At a glance. CNA. 3 April 2020.

77. Cher A. Why Singapore's push to contain coronavirus among migrant workers is so difficult. Health and Science CNBC LLC, 22 April 2020. Available at:https://www.cnbc.com/2020/04/23/ coronavirus-cases-spike-among-singapore-migrant-workers.html. Accessed on 24 July 2020.

78. Channel News Asia. Ministerial statement: Josephine Teo on response to COVID-19 pandemic. Singapore Parliament, 4 May 2020. Available at:https://www.channelnewsasia.com/news/parliament/ videos/may/ministerial-statement-josephine-teo-on-response-toCOVID-19-12700868. Accessed on 27 August 2020.

79. CNA. COVID-19: Cochrane Lodge 2 dormitory declared an isolation area. Channel News Asia. 14 April 2020.

80. Zhuo T. Coronavirus: Dorm standards should be raised, says Josephine Teo. The Straits Times. 7 April 2020.

81. CNA. COVID-19: Four more foreign worker dormitories declared as isolation areas. Channel News Asia. 24 April 2020.

82. Mahmud AH, Ang HM. COVID-19: All foreign worker dormitories to have medical teams of doctors and nurses from hospitals, polyclinics. Channel News Asia. 14 April 2020.

83. Ministry of Manpower. Inter-Agency Taskforce to Support Foreign Workers and Dormitory Operators During Circuit Breaker Period, 2020. Available at:https://www.mom.gov.sg/newsroom/pressreleases/2020/0407-inter-agency-taskforce-to-support-fws-anddormitory-operators-during-circuit-breaker-period. Accessed on 28 July 2020

84. MOH. COVID-19 Local Situation Report (Latest), 2020. Available at:https://www.moh.gov.sg/COVID-19/situation-report. Accessed on 20 August 2020 